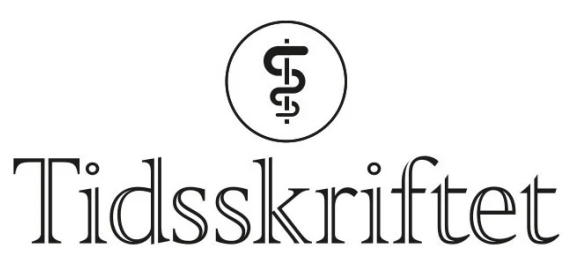

DEN NORSKE LEGEFORENING

\title{
Rettelse: Fremre skulderluksasjon - utredning og behandling
}

RETTELSE

KAARE S. MIDTGAARD

BERTE BØE

KIRSTEN LUNDGREEN

BERND WÜNSCHE

GILBERT MOATSHE

Tidsskr Nor Legeforen 2021; 141: 1074-7.

I Tidsskriftet nr. 11/2021, s. 1076 skal referanse 5 være: Hurley E, Manjunath AK, Bloom DA et al. Arthroscopic Bankart Repair Versus Conservative Management for First-Time Traumatic Anterior Shoulder Instability: A Systematic Review and Meta-analysis. Arthroscopy 2020; 36: 2526-32.

Vi beklager feilen, den er rettet på nett.

Publisert: 9. november 2021. Tidsskr Nor Legeforen. DOI: 10.4045/tidsskr.21.0757

(C) Tidsskrift for Den norske legeforening 2023. Lastet ned fra tidsskriftet.no 26. april 2023. 